\title{
Planning and Management of Coastal Buffer Zones in Taiwan
}

\author{
Yuan-Jyh Lan $1, *\left(\mathbb{D}\right.$ and Tai-Wen Hsu ${ }^{2, *}$ \\ 1 Center of Excellence for Ocean Engineering, National Taiwan Ocean University, Keelung 20224, Taiwan \\ 2 Department of Harbor and River Engineering, National Taiwan Ocean University, Keelung 20224, Taiwan \\ * Correspondence: yjlan@mail.ntou.edu.tw (Y.-J.L.); twhsu@mail.ntou.edu.tw (T.-W.H.); \\ Tel.: +886-2-24622192 (ext. 1240) (Y.-J.L.); +886-2-24622192 (ext. 6104) (T.-W.H.)
}

check for updates

Citation: Lan, Y.-J.; Hsu, T.-W. Planning and Management of Coastal Buffer Zones in Taiwan. Water 2021, 13, 2925. https://doi.org/10.3390/ w13202925

\section{Academic Editors:}

Joaquim Pais-Barbosa

and Carlos Daniel Borges Coelho

Received: 25 August 2021

Accepted: 16 October 2021

Published: 18 October 2021

Publisher's Note: MDPI stays neutral with regard to jurisdictional claims in published maps and institutional affiliations.

Copyright: (c) 2021 by the authors. Licensee MDPI, Basel, Switzerland. This article is an open access article distributed under the terms and conditions of the Creative Commons Attribution (CC BY) license (https:// creativecommons.org/licenses/by/ $4.0 /)$.

\begin{abstract}
Overuse of coastal regions may lead to coastal erosion and shoreline retreat, threatening the inherent life and property of the coast. This is because typhoon waves with storm surges frequently attack overdeveloped coasts and related structures. In the present study, coastal buffer and protection zones were defined for the management of coastal disasters. The coastal buffer zone may offer remarkable advantages to avoid improper coastal use and limit the impact of extreme events by reducing erosion, mitigating coastal disasters, improving water quality, expanding habitats, and minimizing coastal degradation. Further, factors affecting the establishment of coastal buffer zones were classified according to natural and anthropogenic characteristics. Moreover, regarding the direction of research into coastal buffer zones, themes and countermeasures for coastal buffer zone management were discussed from the perspectives of technology, planning, and management policies. Finally, the application of numerical models to assess the impact factors in coastal buffer zones are proposed.
\end{abstract}

Keywords: coastal buffer zone; coastal disasters; impact factors; planning; management; countermeasures

\section{Introduction}

Due to economic and population growth, the use of coastal and marine spaces by humans has increased, and the impact of human activities in some coastal areas has reached the coastline. Human activities and natural disasters have put tremendous pressure on coastal areas, leading to the erosion intensification, retreat of coastlines, and incidence of severe coastal disasters. The coastal environment largely depends on dynamic physical processes, such as waves, ocean currents, wind, sediment stock and littoral drift, and sea level changes. The presence of buildings and facilities in coastal regions may change these physical processes and accelerate the degree of shoreline retreat, such as interrupted coastal sand drift due to groins, jetties, and harbor breakwaters; reduced sediment input; or increased wave energy due to the destruction of coral reefs [1]. In addition, if a seawall is built very close to the coastline and the width of the beach is not enough to dissipate the wave energy, such a seawall may cause high degree of wave reflection and promote strong reverse wave energy, thus shifting the coastal sediment to offshore areas [2]. Although some coastal protection facilities can promote sand accumulation on beaches in small areas, local ocean currents and sediment transport patterns typically change away from protected shores, leading to coastal erosion elsewhere [3]. Coupled with climate change and its impacts (such as sea level rise, storm intensity and patterns, and increased coastal flooding) will increase the risk of coastline retreat.

The interpretation of "coastal area/system," particularly its land part, varies across countries [4]. The methods for defining coastal systems are classified into management units, human use dynamics, area coverage of coastal zones, and ecosystem functions [5]. For instance, the land boundary of Germany is based on the area under the jurisdiction of the administrative department; in the context of global climate change, land within $100 \mathrm{~km}$ of the coastline is often used as the boundary. Eurostat defines EU coastal systems as standard statistical regions (the Nomenclature of Territorial Units for Statistics, NUTS 
3 level), which have at least half of their population within $50 \mathrm{~km}$ of the coast [4]. However, in terms of actual planning regions to be protected, the scope of the "coastal area/system" is much smaller. Lithuania defines the land part of the coastal system as region within 3-5 km from the coastline, whereas Denmark defines it as the area within $3 \mathrm{~km}$ of the coastline [6]. According to the Coastal Zone Management Act of Taiwan [7], the delimitation principles for coastal systems are as follows:

1. Shore land area: The area from the average high tide line to the first provincial highway, coastal road, or mountain ridge;

2. Offshore area: The area from the average high tide line to the $30-\mathrm{m}$ isobath or three nautical miles towards the sea, whichever is longer, but not exceeding the territorial sea and its seabed and subsoil.

In fact, the topography of the coastline and adjacent areas varies with ocean currents, tides, cyclone and storm waves, and coastal currents. On naturally balanced coasts, the shoreline remains in a "dynamic equilibrium" state. Therefore, a transition zone of coastal change should be marked at the land-sea junction in the coastal area. This transition zone can promote the dissipation of wave energy and maintain the balance of sediment transport, acting as a buffer to mitigate and prevent coastal disasters. Coastal disasters caused by wave energy can be avoided through the design and management of a coastal buffer zone, offering a protective barrier between land-based activities and adjacent coastal waters [8].

In recent years, countermeasures for the prevention and mitigation of coastal disasters have gradually shifted from localized management schemes to ones which consider the broader environmental setting. Countries adjacent to oceans are paying increased attention to and strengthening adaptation strategies and action plans for coastal areas in the face of climate change and sea level rise [9-15]. Launched in 2005 by the Water Resources Agency, Ministry of Economic Affairs, Taiwan, the strategy for coastal sustainability was a national-scale initiative intended to address coastal issues based on a detailed diagnosis. For sustainable utilization of coastal areas, establishment of optimized coastal buffer and protection zones were proposed to formulate or administer coastal management programs. Specifically, a coastal buffer zone is a permanent conflict mitigation area near coastal waters and is defined by the width parameter. The buffer zone can serve as the potential line of defense to prevent beach transition, improve water quality, and maintain habitats in aquatic and coastal environments. Establishment of such a buffer zone is key to the centralized management and mitigation of coastal disasters. The water and land boundaries of the buffer zone are designed to provide the most effective buffer for the energy dissipation of waves propagating from deep waters to coastline. A beach of sufficient width is a natural buffer against high energetic waves and storm surges $[2,16]$. Therefore, the establishment of a coastal buffer zone is expected to play pivotal roles in adapting to changes in coastal physical processes. At present, however, there is paucity of a comprehensive definition of the coastal buffer zone.

The present article summarizes the findings of research on the establishment of coastal buffer zones under the sustainable coastal development strategy of Taiwan over the last 15 years for the management and mitigation of coastal disasters in longshore areas. First, the coastal buffer and protection zones are defined from the perspective of coastal disaster prevention and protection. Next, factors affecting the establishment of coastal buffer zones are discussed based on natural and anthropogenic characteristics. Moreover, suitable numerical models that can be applied to identify the impact factors of coastal buffer zones are proposed. Finally, regarding the direction of research on coastal buffer zones, the management of coastal buffer zones is discussed from the viewpoints of technology, planning, and policy-making. Specifically, approaches for the delineation of coastal buffer zones and recommendations for their planning and management in the future are detailed.

\section{Definition of the Coastal Buffer Zone}

The terms buffer zone, buffer region, or buffer strip are used mostly in the context of rivers, ecology, and environmental conservation [17-23]. Although there are relatively few 
reports and studies on actual coastal performance, the functional mechanisms applicable to inland riparian buffer zones can also be applied to coastal buffer zones for achieving a better balance between coastal resource protection and development [24].

The coastal buffer zone is the transition area between land and sea spaces, encompassing lagoons and intertidal zones. Since there is no clear universal definition of the coastal buffer zone, scholars in different professional fields of science, biology, and physics have proposed diverse definitions of the coastal buffer zone. For instance, in the field of marine physics, the coastal buffer zone is the region between the nearshore and ocean currents, as shown in Figure 1 [25]. Kuo and Chang [26] introduced coastal buffer zones based on marine ecology and environmental science. According to them, the coastal buffer zone extends from the waterline between the ocean and the land to a depth of 20 or $30 \mathrm{~m}$ in the sea, where underwater plants can photosynthesize. According to the waterline conditions that can be reached by waves and tides, the coastal buffer zone can be divided into three parts (Figure 2): the area reachable by waves is called the supratidal zone; the area between the high tide line and the low tide line is called the intertidal zone; and the area below the low tide line is called the subtidal zone. In addition, according to Park et al. [27], the characteristics of the groundwater level can be used to establish coastal buffer zones on natural beaches.

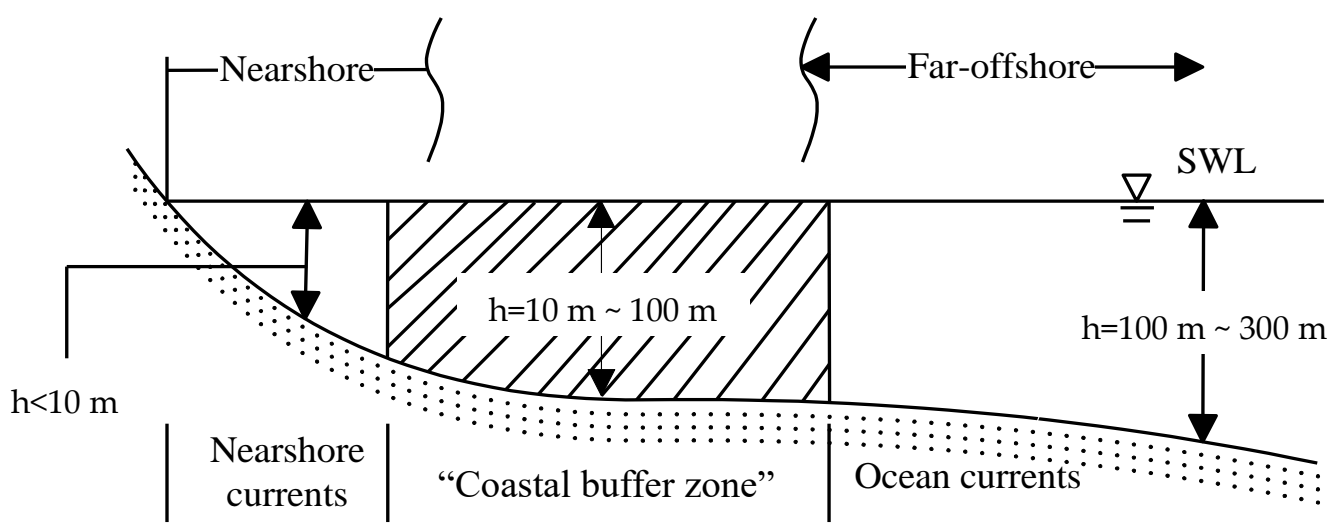

Figure 1. Definition of coastal buffer zone based on marine physics [25].

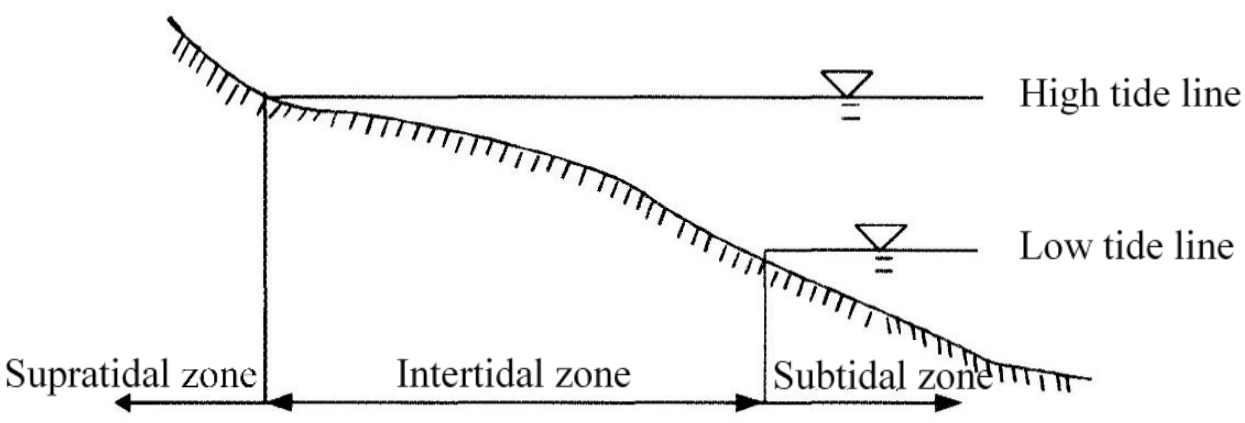

Figure 2. Definition of coastal buffer zone based on marine ecology and environmental science [26].

Therefore, to establish a clear, universal definition of the coastal buffer zone, collaboration among relevant experts and governments is essential. The experts from various parties and relevant government agencies in Taiwan were invited to discuss and reach a consensus. Accordingly, the coastal buffer zone can be defined from two perspectives: disaster prevention and coastal protection [28]:

1. Definition from the perspectives of coastal dynamic systems and processes:

In terms of its land part, the coastal buffer zone should be defined as the area that can be reached by seawater. The broad definition should include coastal flooding areas by typhoons and storm surges. In the water part of the coastal buffer zone, areas with obvious sediment 
drift and transport should be included. The narrow limit can be set within the range of significant nearshore currents (water depth of 5-10 m), and the broad limit can be extended to the range where tidal currents affect sediment drifting (water depth of $20-30 \mathrm{~m}$ or deeper);

2. Definition from the perspective of disaster prevention:

The coastal buffer zone can be defined as the region where the coastal disasters (such as typhoon wave height, storm surge, or nearshore currents) are reduced or eliminated. The range of this buffer zone can only include sea or land areas.

In the face of sea level rise and other severe coastal disasters as a result of climate change, we believe that it is appropriate to define the coastal buffer and protection zone from the perspective of disaster prevention and protection. Therefore, we adopted the following definitions to establish the coastal protection and buffer zones (Figure 3):

- Coastal protection zone:

$>\quad$ Aspect of land basin: area where coastal flooding may occur due to typhoons or storm surges;

$>\quad$ Aspect of ocean area: the farthest range of sediment drift induced by tidal currents.

- Coastal buffer zone:

$>\quad$ Aspect of land basin: the area that may be reached directly by seawater due to typhoons or storm surges, or that presents buffering factors to minimize the occurrence of disasters;

$>\quad$ Aspect of ocean area: the farthest range of sediment drift induced by nearshore currents, or the area that presents buffering factors to minimize the occurrence of disasters.

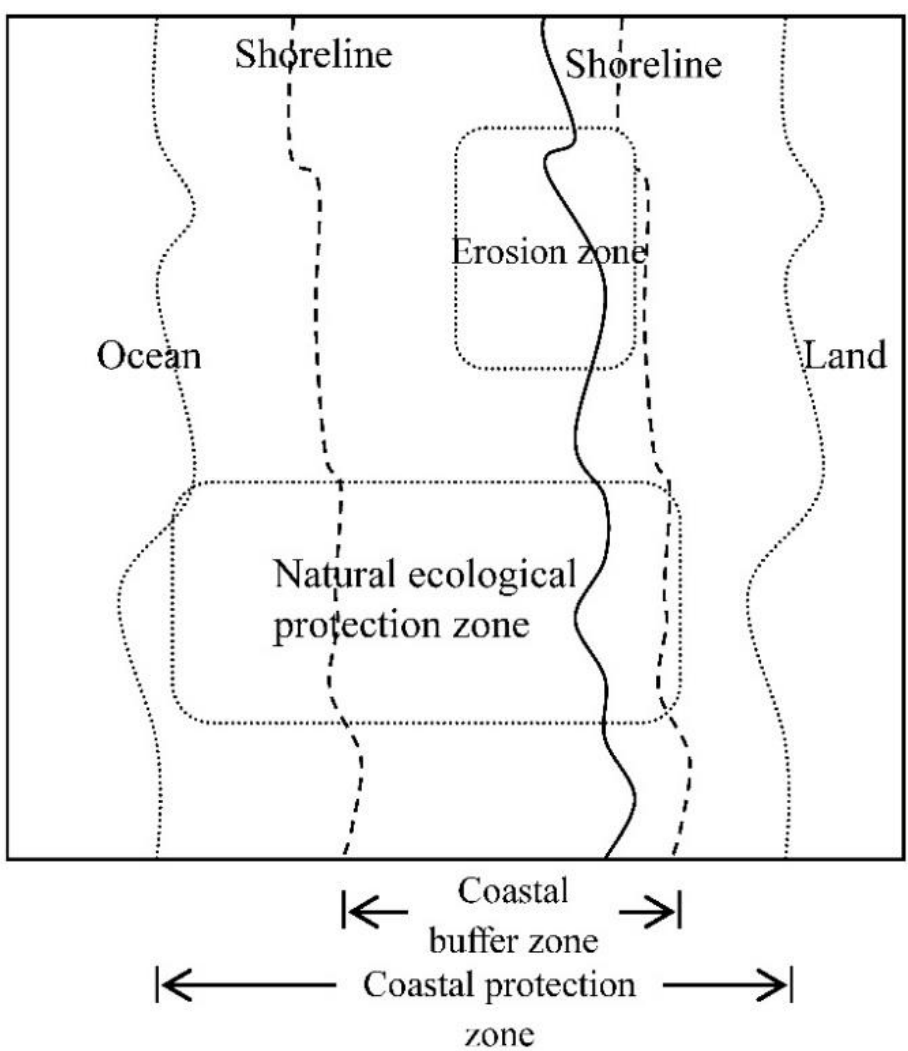

Figure 3. Sketch of coastal buffer and protection zones.

In Taiwan, the designation of coastal protection and buffer zones is based on typhoon waves and their resultant storm surges during a return period of 50 years as the input conditions. The suitability of the designated area is reviewed every ten years. 


\section{Recommendations for the Management and Administration of Coastal Buffer Zones}

The planning and management of coastal buffer zones can be divided into two spatial directions, namely, land and nearshore sea areas, and then further combined into the entire strip. In addition to coastline and surface protection, research in the entire region must focus on coastal ecology, disaster prevention, and landscape recreation (Figure 4) [29]. Therefore, the concerned issues of coastal buffer zones must involve three aspects: technology, planning and management, and policy-making.
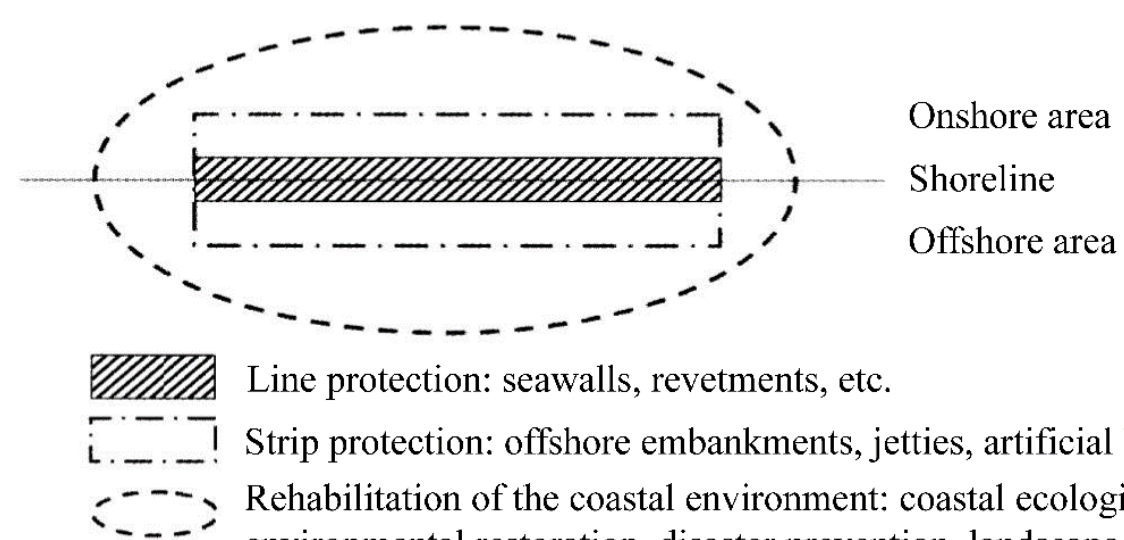

Line protection: seawalls, revetments, etc.

Strip protection: offshore embankments, jetties, artificial beaches, etc.

- n

Rehabilitation of the coastal environment: coastal ecological and environmental restoration, disaster prevention, landscape recreation, etc.

Figure 4. Research direction for coastal buffer zone management [29].

\subsection{Aspect of Technology}

Applying relevant research technologies to understand the characteristics of the impact factors of coastal buffer zones and their effects in preventing waves, reducing tidal currents, or delaying tidal waves from attacking natural or artificial structures is essential to ensure the sustainable use of coastal buffer zones. According to the basic definition of the coastal buffer zone proposed in the present study, the impact factors of the coastal buffer zone can be divided into two parts: natural and anthropogenic impact factors (Figure 5) [8].

1. Natural impact factors:

- Geographical characteristics: Beaches, reef coasts, wetlands, lagoons and tide pools, sand dunes, algae fields, submerged reefs, headlands, bays, estuary bars, islands, and coastline shape (straight or curved);

- Hydrological characteristics: Groundwater level, river flow conditions, river channel shape, channel elevation, and estuary sediment transport;

- Ocean and meteorological characteristics: Waves, tides, tidal currents, nearshore currents, typhoons, storm surges, and coastal sediment transport;

- Biological characteristics: Aquatic species, intertidal species, and terrestrial species;

- Environmental factors: Water quality, pollutants, nutrients, suitable habitat flow, and stratum subsidence.

2. Anthropogenic impact factors (the coastline is used as the partition):

- Artificial structures in the sea, such as artificial islands, artificial sneak reefs, and offshore embankments;

- Artificial structures on the coast, such as breakwaters, ports, reclaimed land, jetties, artificial headlands, groins, seawalls, revetments, diversion dikes, artificial beaches, and artificial wetlands;

- Artificial structures on the land, such as sand fences, sand fixers, windbreaks, disaster prevention drainage facilities, and other artificial structures (such as roads, houses, fishponds, and agricultural land) located in the coastal buffer zone. 


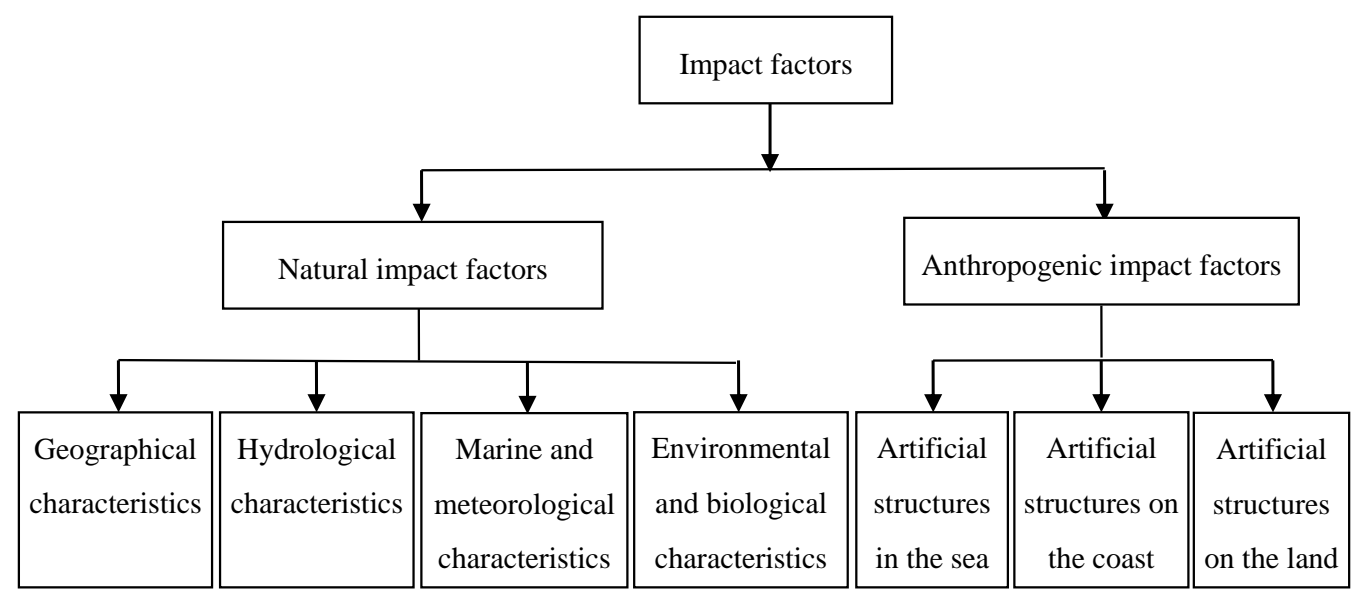

Figure 5. Impact factors of the coastal buffer zone [8].

Research on coastal buffer zones must consider the existing impact factors in coastal areas to understand their degree of effect on the prevention of natural disasters, coastal conservation, and ecology. We propose the division of the coastal area into coastal erosion, flooding, and storm surge subareas. The basis for this division must consider integrated studies on hydrodynamics, environment, and ecology. Furthermore, the research methods should include long-term field surveys, model experimental analyses, and numerical model simulations. In research applying numerical models, the following methods can be used to identify the impact factors of the coastal buffer zones (Figure 6):

1. Numerical models such as the wind wave models (e.g., WAM, SWAN, STWAVE, TOMAWAC, and WWM), nearshore wave field models (based on the mild-slope equation or Boussinesq-type equation, among others), wave run-up models (e.g., see Mase [30] and De Waal and van der Meer [31]), and others [32,33] can simulate and predict the wave conditions of the coastal buffer zone;

2. Numerical models such as the tide models (e.g., see Zalesny et al. [34]), nearshore current models (e.g., see Svendsen et al. [35]), and estuary dynamic models (e.g., see Pao et al. [36]) can simulate and predict the flow conditions of the coastal buffer zone;

3. Numerical models such as the sea level rise models (e.g., see Dayan et al. [37]), tidal level and storm surge models (e.g., see Dube et al. [38], Kim et al. [39], and Muis et al. [40]), coastal overflow and flooding models (e.g., see Gallien et al. [41] and Xie et al. [42]) can predict the potential rise in sea level and the possible range of flooding in the coastal buffer zone;

4. Numerical model such as the shoreline and topography change models for sea areas (e.g., GENESIS and SPEACH [43-45]), headland theory models (e.g., see Hsu and Evans [46], Weesakul et al. [47], and Li et al. [48]), estuary sediment transport model (e.g., see Pao et al. [36]), and wind sand models (e.g., see Lo Giudice and Preziosi [49]) can predict the potential movement of sediment and dune sand in the coastal buffer zone as well as the changes in shoreline and topography of sea and land areas;

5. Numerical model such as the pollution diffusion models (e.g., see James [50]), salinity or temperature distribution models (e.g., see Larson et al. [51] and Pu et al. [52]), and groundwater seepage models (e.g., see Park, et al. [26]) can predict water quality based on the concentration and distribution of nutrients and pollutants in the coastal buffer zone;

6. Ecological habitat models (e.g., see Xu et al. [53]) and ecological engineering methods (e.g., Sulaiman and Mohidin [54]) can predict the distribution of suitable habitats for organisms in the coastal buffer zone and applicable ecological engineering. 


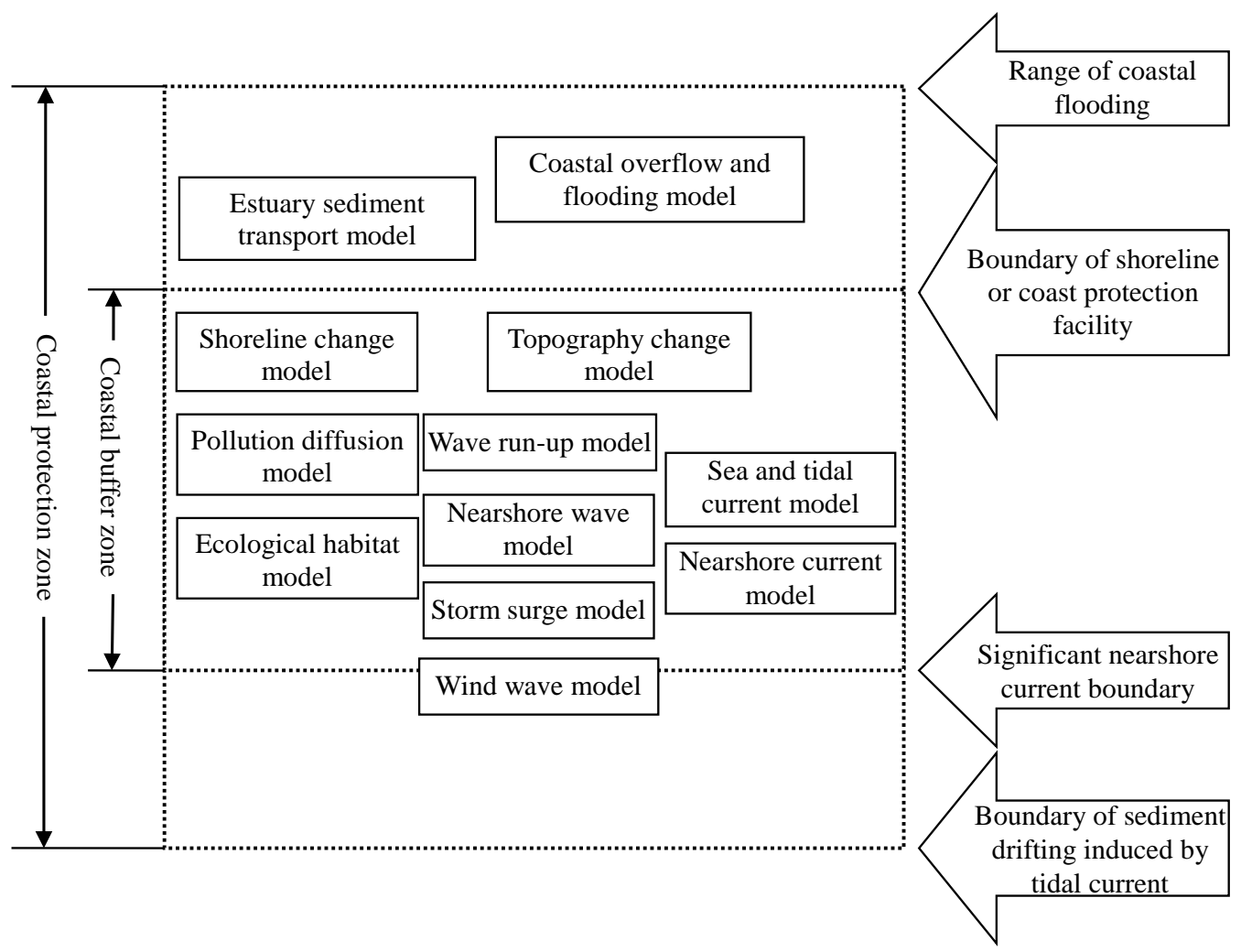

Figure 6. Schematic diagram of research on the application of numerical models to identify the impact factors of coastal buffer zones.

Based on the hydrodynamics of and sediment transport by nearshore and tidal currents, Lan et al. [55,56] and $\mathrm{Li}[57]$ proposed a method for determining the boundaries of offshore and onshore areas in the coastal buffer zone (Figure 7). They used the SBEACH model combined with the wave run-up model $\left(\right.$ Flow3 $\mathrm{D}^{\circledR}$ ) to perform dynamic simulations of beach profile changes on different sections of the coast at the present state of sea level, and then set the boundaries of the offshore and onshore areas of the coastal buffer zone based on the typhoon waves during the 50-year return period, as shown in Figures 8 and 9 . The offshore boundary is bounded by the farthest range of sediment drift simulated by the SBEACH model, and the onshore boundary is set at the maximum height of wave run-up. The preliminary delineation range was verified with the current coastal resources and coastal environmental impact factors, and a comprehensive analysis was conducted to establish the final range of the coastal buffer zone [58].

Focusing on the problems of special coastal areas, such as harbors, estuaries, coastal industrial areas, and small islands, Lan et al. [56] put forth the following suggestions regarding the appropriate layout of coastal buffer zones:

1. For large harbors, because the breakwater extends to the open sea beyond the offshore boundary of the coastal buffer zone, there is no offshore boundary line for the region. Thus, the delineation of the onshore boundary also follows this principle;

2. In estuarine areas, the onshore boundary of the coastal buffer zone should preferably connect with the riparian buffer zone;

3. Small islands are surrounded by sea on all sides, and the intensity of typhoon waves varies in different seaward directions. Therefore, the buffer zone for each coastal segment simulated by the hydrodynamic models will also be different. Thus, the offshore boundary of the coastal buffer zone of small islands should be set at the farthest water depth of sediment transportation as the unified boundary. 


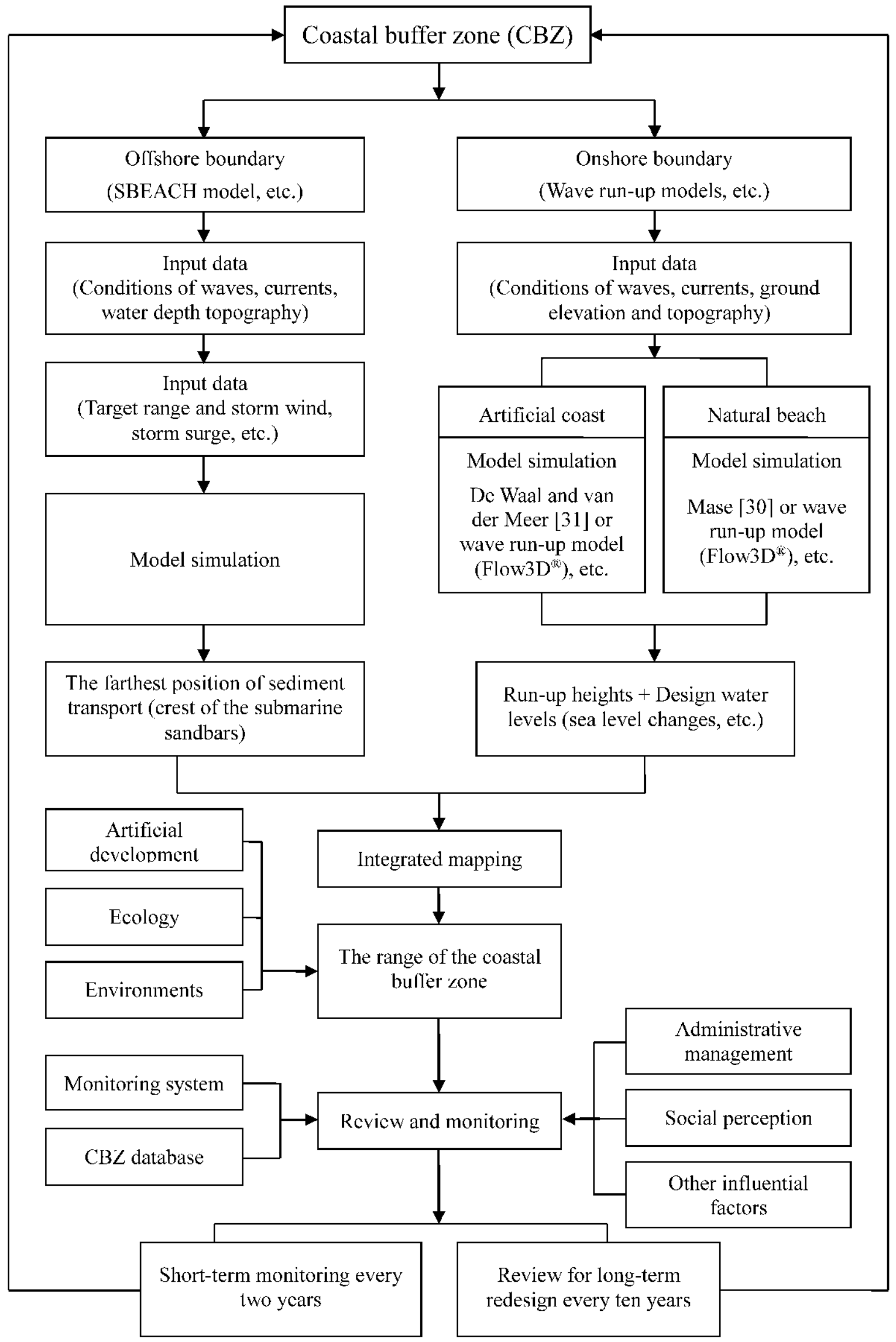

Figure 7. Recommended flow chart to design coastal buffer zones for coastal managers. 


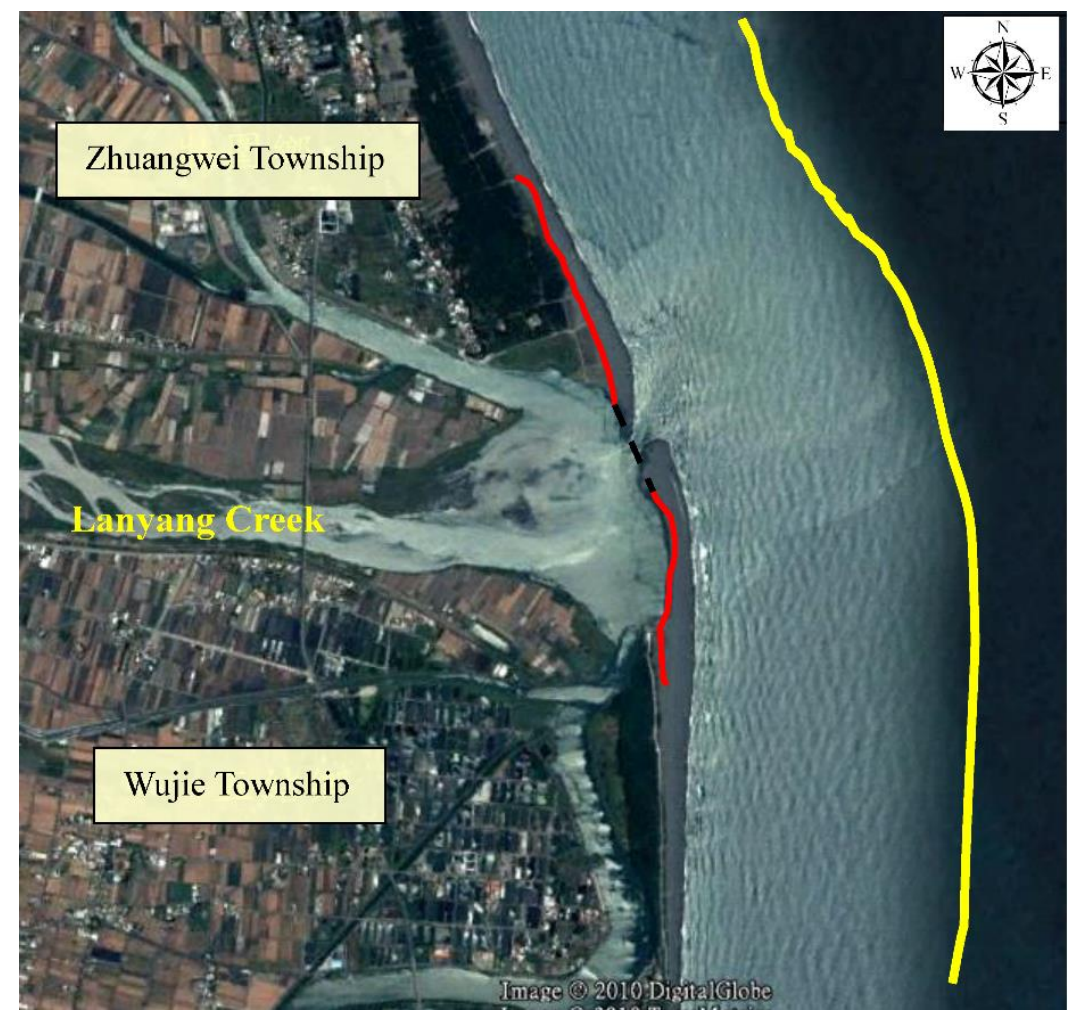

Figure 8. Preliminary planning results of coastal buffer zone using the SBEACH and wave run-up models (the estuary of Lanyang Creek, Yilan, Taiwan) [56]. (Red line: the onshore boundary of the coastal buffer zone; yellow line: the offshore boundary of the coastal buffer zone.).

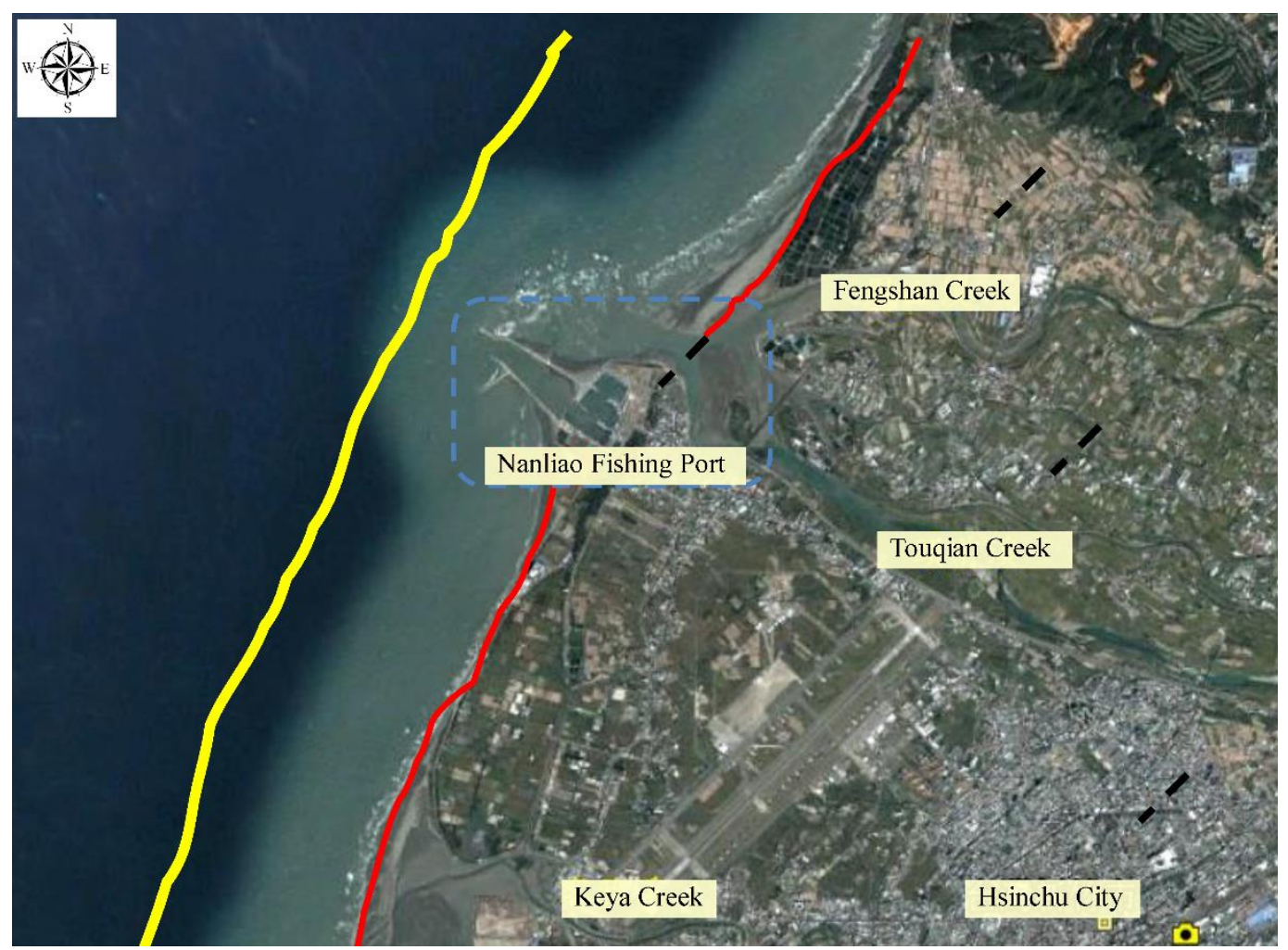

Figure 9. Preliminary planning results of coastal buffer zone using the SBEACH and wave run-up models (Nanliao Fishing Port, Hsinchu, Taiwan) [56]. (Red line: the onshore boundary of the coastal buffer zone; yellow line: the offshore boundary of the coastal buffer zone.). 


\subsection{Aspects of Planning and Management}

The coastal buffer zone, defined as the strip-shaped transition zone between the sea and land, is part of the coastal protection zone. Owing to their diverse geographical, ecological, and environmental attributes, coastal protection zones present different characteristics of coastal erosion, ecological environment, flooding, and storm surge, among others. Therefore, the buffer zone of each coastal segment serves different functions in disaster prevention, mitigation, and protection, and each zone has unique management characteristics and approaches. In addition, different management strategies adapted to local conditions are employed to cope with different characteristics and purposes [59]. The zoning of coastal buffer region is an effective method for management. Therefore, clear and comprehensive rules should be formulated for the use and restriction of these zones, and the attributes of each zone should be planned. Within the coastal buffer zones, relevant information on the geography and ecology must be collected using scientific approaches, monitored, and timely updated to facilitate management and adjustment.

Overall, the planning of coastal buffer zones is universal and comprehensive. The range of the buffer zone inevitably overlaps with coastal areas under other uses, such as coastal wetlands, coastal nature reserves, ports, and coastal industrial areas. Therefore, the integration of various delimited areas should be analyzed and discussed [60]. Integrated analysis can be divided into comparative analyses of general and different management aspects. The aspects for general comparative analysis include purpose and subject, design method, scope, and impact factors. Factors to be considered in the delineation of the offshore and onshore boundaries of the coastal buffer zone and the necessity of changing these boundaries can be explored by sorting the various current utilization methods of the target coastal area and discussing their similarities, differences, and mutual relations. In the comparative analysis of different management aspects, authorities, projects, principles, and methods among the buffer zones and areas designated for other purposes of the target coast can be analyzed to explore their similarities, differences, and mutual relations.

Figure 10 presents the case study of the Haomeiliao coast in Chiayi, Taiwan. This area covers a coastal nature reserve (red line) and wetland area (yellow line) as well as the coastal buffer zone proposed in the present research (green line). Results of the comparative analysis of the buffer zone and nature reserve of the Haomeiliao coast are presented in Tables 1 and 2. In the presence of multiple regional boundaries for different purposes within the same coastal area, management becomes extremely complex and monitoring and law enforcement are difficult. Therefore, the complex regional boundaries must be reviewed, and the adjacent boundaries must be adjusted to the same type of management. For instance, as shown in Figure 10, the offshore boundary of the Haomeiliao wetland is set according to the Ramsar Convention at a water depth of $6 \mathrm{~m}$, which is not far from the offshore boundary of the coastal buffer zone (at a water depth of $5 \mathrm{~m}$ ). Therefore, to reduce the difficulties in planning and management, the offshore boundary of the coastal buffer zone can be adjusted to coincide with the offshore boundary of the coastal wetland [58].

The management of the coastal buffer zone should adopt a zoning system [60]. Following the delineation of offshore and onshore boundaries, the coastal buffer zone should be appropriately divided into several subzones taking the administrative jurisdiction, usage, topography, ecological integrity, and management convenience into account.

The following methods can be used for the division of the coastal buffer zone into subzones:

1. Use of administrative districts as the division boundaries;

2. Cooperation with the river catchment area as the zoning method;

3. Division based on topographic attributes (e.g., sandy or rocky shore);

4. Division based on natural attributes (e.g., natural or artificial coast);

5. Division based on the purpose of use (e.g., development area, recreation area, protection area, or harbor);

6. Division based on coastal conditions (e.g., stable, vulnerable, or protected section). 


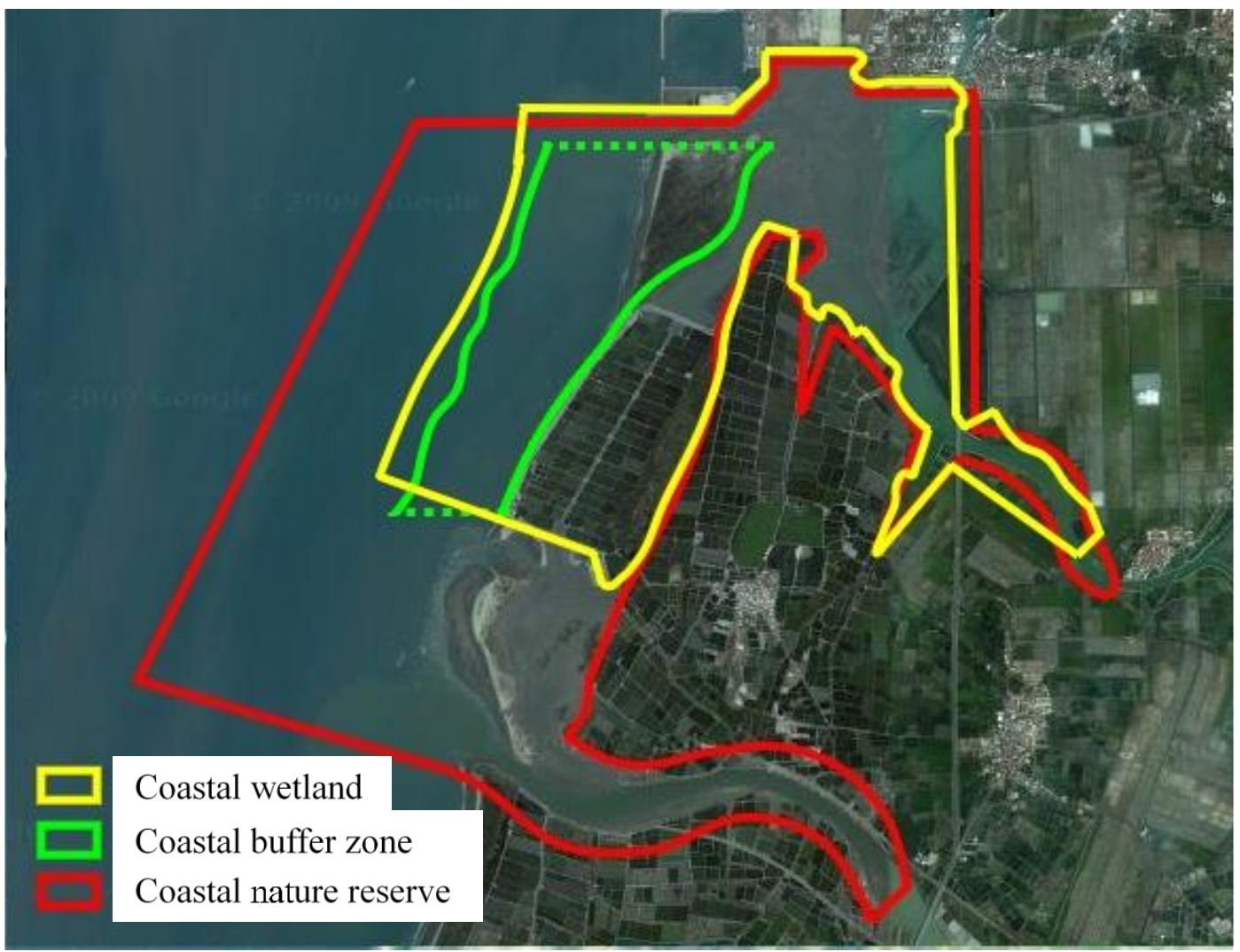

Figure 10. Zoning boundaries for various purposes in the coastal area (Howmeiliao Coast, Chiayi, Taiwan) [58].

Table 1. General comparative analysis of coastal buffer zone and nature reserve (Howmeiliao Coast, Chiayi, Taiwan) (based on Lan et al. [60]).

\begin{tabular}{|c|c|c|}
\hline \multicolumn{3}{|c|}{ General Comparative Analysis } \\
\hline Item & Coastal Buffer Zone & Nature Reserve \\
\hline Purpose and subject & $\begin{array}{l}\text { Restoration of the coastal environment and maintenance of } \\
\text { the natural coastal transition processes }\end{array}$ & Protection of precious natural resources \\
\hline Design method & Theoretical basis: hydrodynamic theory & Comprehensive theoretical and legal bases \\
\hline Scope & Strip or ring concept; general properties & Block distribution; special properties \\
\hline Impact factors & $\begin{array}{l}\text { Natural impact factors: geographical, hydrological, marine, } \\
\text { meteorological, environmental, and biological } \\
\text { characteristics } \\
\text { Anthropogenic impact factors: artificial structures in the } \\
\text { sea, on the coast, and on the land }\end{array}$ & $\begin{array}{l}\text { Coastal water flow, chemical composition, salinity, } \\
\text { soluble gases, water temperature, sunshine, } \\
\text { sedimentation, and pathogenic organisms }\end{array}$ \\
\hline
\end{tabular}

Table 2. Management project comparative analysis of coastal buffer zone and nature reserve (Howmeiliao Coast, Chiayi, Taiwan) (based on Lan et al. [60]).

\begin{tabular}{|c|c|c|}
\hline \multicolumn{3}{|c|}{ Management Project Comparative Analysis } \\
\hline Item & Coastal Buffer Zone & Nature Reserve \\
\hline Management authority & $\begin{array}{c}\text { Ocean Conservation Administration, } \\
\text { Ocean Affairs Council } \S\end{array}$ & $\begin{array}{l}\text { Local government, Forestry Bureau, } \\
\text { Council of Agriculture }\end{array}$ \\
\hline Management project & $\begin{array}{l}\text { Parallel "prevention" and "treatment" and early } \\
\text { warning management, in addition to regulating } \\
\text { matters occurring in the zone; any activities must be } \\
\text { restricted if they are likely to affect other coastal areas }\end{array}$ & $\begin{array}{c}\text { Prohibit or restrict certain items; only stipulate } \\
\text { matters within the scope of protection (i.e., } \\
\text { partial specification) }\end{array}$ \\
\hline Management principle & $\begin{array}{l}\text { Principles of public participation, zoning } \\
\text { management, and early warning and establishment } \\
\text { of information management and monitoring systems }\end{array}$ & $\begin{array}{l}\text { Development of a permit system, environmental } \\
\text { impact assessment, and concept of absoluteness }\end{array}$ \\
\hline Management method & Active response & Passive response \\
\hline
\end{tabular}

\footnotetext{
$\S$ Ocean Conservation Administration and Ocean Affairs Council of Taiwan were established in 2018.
} 


\subsection{Aspect of Strategy}

A successful management strategy for coastal buffer zones must be implemented effectively. In addition to effective law enforcement, it must cover mass education, communication and cooperation, environmental physical investigation, and ocean monitoring, among other factors. Stringent law enforcement with clear regulations is the key aspect. Formulation of laws is one of the most direct and effective ways to implement and manage coastal buffer zones. The legislation of the coastal buffer zone must be properly implemented and accepted by the public.

The buffer zone must consider coastal development, protection, and ecological conservation. As the coastline changes over time due to natural and external anthropogenic factors, the definition of the coastal buffer zone must be adjusted according to the changing conditions. Formulation of regional management regulations must take into account the characteristics of the local coast and draw on the experiences of overseas countries (such as Japan, the United States, the Netherlands, Germany, Spain, and Taiwan) to develop suitable management specifications for the coastal buffer zone. The following policies should be emphasized in the coastal buffer zone:

\section{Sound management regulations and mechanisms}

Establishment of a single competent authority responsible for formulating a holistic and forward-looking coastal management policy is more efficient. The management power of the coastal buffer zone should be implemented uniformly by the central government. The participation rights of the local governments should be introduced through the formulation of exclusive legal rules. For instance, the Legislative Yuan of Taiwan passed and implemented the Coastal Management Law in 2015. In 2018, the exclusive agency of the Ocean Affairs Council was established, which is responsible for coordinating various affairs and enacting related laws, retaining the general command and supervision power over coastal areas. Management of numerous specific affairs and law enforcement are appointed to local agencies proficient in regional operations.

Public participation should be introduced when formulating the rules of the coastal buffer zone, and all stakeholders should participate in the formulation and implementation of related decisions. Complete awareness and participation of stakeholders will help determine and allocate appropriate corresponding responsibilities and formulate credible and standard rules [61].

2. Coastal management information and environmental monitoring systems

The management of coastal buffer zones should follow the principle of early warning. The early warning principle can be applied to coastal buffer zones with two management options:

- Principle of ecological compensation

Damage to the ecological function or value caused by the construction of a project can be compensated for through habitat creation, restoration, enhancement, or preservation, such that the overall ecological quality can be maintained or improved.

In 1990, in the Memorandum of Agreement between the United States Environmental Protection Agency and the Department of the Army, the principle of mitigation sequence was proposed. According to this principle, the order of implementing ecological compensation should be based on the procedures of avoidance, mitigation, and compensation. In Taiwan, a study by the National Land Planning and Real Estate Information Center (NLPREIC) also recommended the establishment of a shock compensation mechanism, that is, an effective system to slow down development shocks and adopt prudent and effective construction methods to restore the vitality of oceans [62]. In the 2021 amendment of the article 27 of the Environmental Impact Assessment Guidelines for Development Behaviors by the Environmental Protection Administration of Taiwan, preventive measures against environmental impacts are introduced. Specifically, development plans in coastal areas should comply with the following: (a) avoid impact on important ecological habitats or normal ecosystem function; (b) avoid serious damage to aquatic resources; (c) avoid coastal erosion, 
siltation, stratum subsidence, flooding, etc.; (d) avoid damage to marine landscapes, recreational resources, and underwater cultural assets; and (e) maintain a hydrophilic space [63] Therefore, these principles of ecological compensation can also be applied to the principles of environmental compensation in the management of coastal buffer zones. Before the implementation of anthropogenic measures for the development or protection of a coastal area, accurate environmental impact assessments must be conducted. The assessment scope should be specified according to the scale, and procedures of avoidance, mitigation, and compensation should be adopted. Finally, an environmental compensation mechanism should be formulated to achieve the spirit of the early warning principle.

- Environmental Funds

Environmental funds provide protection against not only known environmental impacts but also unknown factors. The early warning environmental security deposit system operates as follows [64]:

(1) In addition to charging directly for the known environmental damage, it also charges a certain amount of security for potential future environmental damage;

(2) To retain the promise of the pre-warning principle, the amount of this deposit depends on the expected value of the maximum decision-making bet (the worst result) estimated by the environmental experts of the public sector using the current best estimation techniques, and the deposit is "detained" and deposited in an escrow account with interest income.

According to the direction specified by the government laws, the environmental fund system should be clearly defined in the legislative design of the coastal buffer zone. Expropriation objects include developers in neighboring areas, who must pay development impact fees. Implementers of artificial changes for protection purposes must also pay environmental funds in advance. In addition to improving the unanticipated environmental damage in the future, environmental funds can also be used for environmental monitoring, information collection, and technical implementation.

In addition, a coastal buffer zone monitoring system and database should be built to support the coastal management information and environmental monitoring systems. In Taiwan's 21st Century Agenda: National Sustainable Development Vision and Strategic Guidelines, strategies for "integrating marine management systems and establishing marine and coastal monitoring systems" as well as "building coastal environmental monitoring systems and database construction plans" were proposed. A monitoring center should be established in each subzone of the coastal buffer zone for investigation, supervision, command, and law enforcement. In addition, the central competent authority should build a database center to collect, store, analyze, and circulate data and maintain a network of marine and coastal management systems. The main tasks of this database center are to collect, compile, and analyze the data from each monitoring center; communicate with other marine and coastal research and management centers; and maximize the use of information.

3. Sound coastal management organization and personnel training

Coastal areas are highly sensitive and vulnerable zones, which are important for the socio-economic development of many countries. Therefore, sound management organization and advanced professional foundation are essential. Management systems should focus on comprehensive personal training and communication.

4. Emphasis on the conservation of coastal wetlands and natural coasts

The spirit of the management of the coastal buffer zone is to "minimize human intervention as much as possible for restoring the natural function of the coastline" [58]. Coastal wetlands and natural coasts are important for the integrity of the coastal ecological environment [65]. In the past, following the economic development-oriented thinking, wetlands with rich ecological productivity were often sacrificed. The maintenance and conservation of natural coasts and wetlands should be strengthened by the related governments. 
Therefore, in addition to management and conservation to reduce the impact on coastal changes and use of compensation principle to maintain natural coasts, small-scale uses of coastal buffer zones, such as long-term waste storage at the beach and water diversion facilities for aquaculture, must also be controlled through proper management. Tourism and leisure activities should ensure the safety and environmental tolerance of the beach area, consider the impact of crowd on the environment, limit the maximum allowable amount, prohibit the digging of beach sand or collecting plants and other behaviors that destroy the terrain and landforms, and promote recreational activities that have low demand for facilities and do not burden the environment. Reserve and respect the natural space and establish the concept of accumulative capacity of "just enough to stop".

\section{Summary}

In the past, people only considered economic aspects when developing coastal areas in a district, which led to the over-utilization of many coastal buffers. As a result of consequent land erosion, the coastal buffer zones retreated or even disappeared. Therefore, the issue of coastal buffer zones has garnered much attention in recent years. In the present article, we proposed clear, universal definitions of coastal protection and buffer zones from the perspectives of coastal disaster prevention and protection and explained their scope. We recommend using certain major natural and anthropogenic impact factors as the bases for the research and design of coastal buffer zones. Regarding research direction for the establishment and operation of coastal buffer zones, we discussed the topics of coastal environmental restoration as well as prevention and mitigation of coastal disasters from the viewpoints of technology, management, planning, and policy-making. We summarized numerical models that can be applied to identify the impact factors of coastal buffer zones. Finally, we integrated recommendations on the establishment and management of coastal buffer zones into a research framework, as shown in Figure 11. We expect that the establishment of buffer zones will achieve sustainable and sound development in coastal areas while preventing natural disasters, maintaining ecosystem function, and ensuring environmental regeneration.

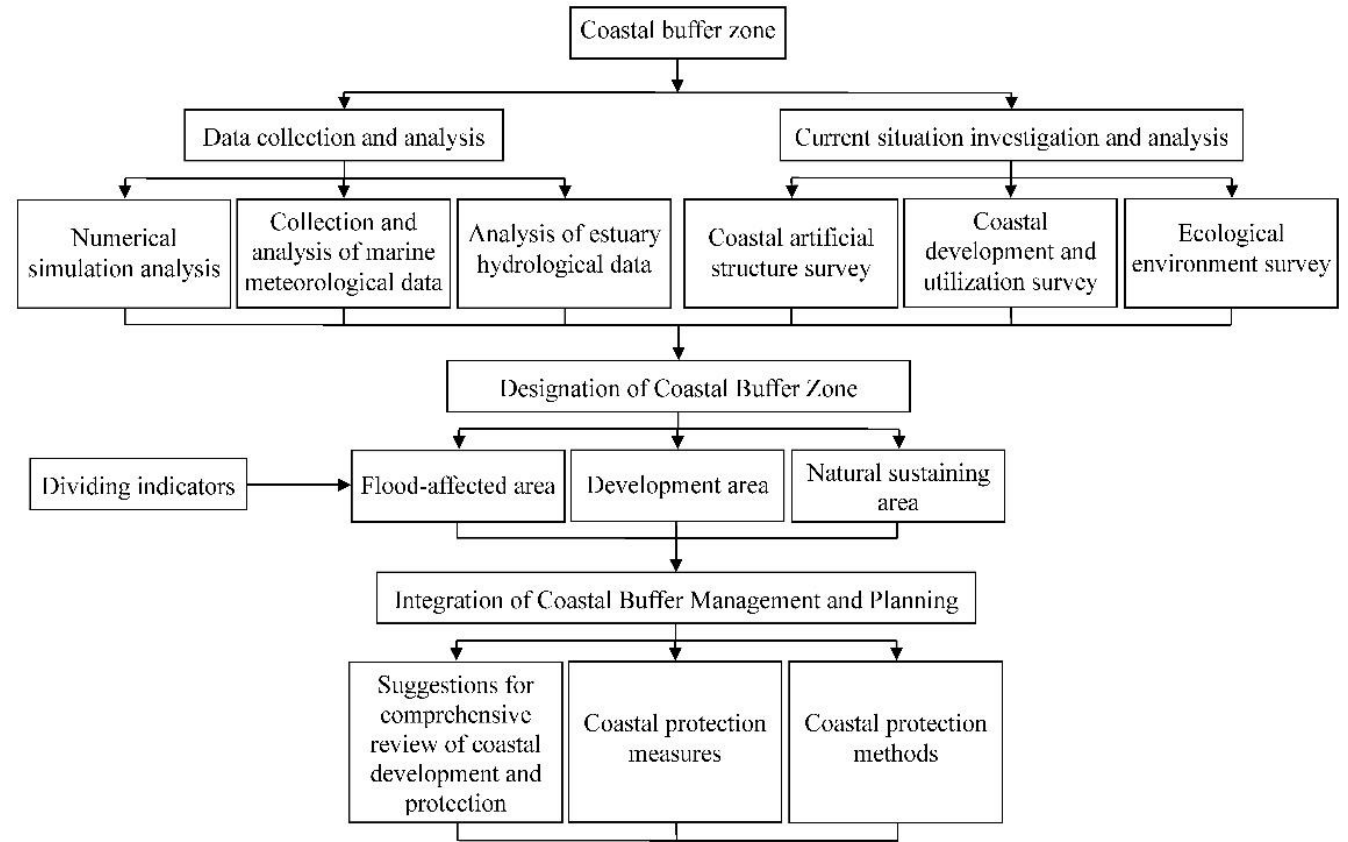

Figure 11. Research framework for the establishment and management of coastal buffer zones.

Author Contributions: Conceptualization, T.-W.H. and Y.-J.L.; methodology, T.-W.H. and Y.-J.L.; formal analysis, Y.-J.L.; investigation, Y.-J.L.; writing—original draft preparation, Y.-J.L.; writing—review and editing, T.-W.H. and Y.-J.L. All authors have read and agreed to the published version of the manuscript. 
Funding: This research was funded by the Ministry of Science and Technology, Taiwan, under Grant No. NSC 99-2221-E-006-237. The support of the Ministry of Education subsidized the Higher Education Deep Cultivation Program-Featured Fields in 2021 is also acknowledged.

Institutional Review Board Statement: Not applicable.

Informed Consent Statement: Not applicable.

Data Availability Statement: No data reported in this study.

Conflicts of Interest: The authors declare no conflict of interest.

\section{References}

1. Bird, E.C.F. Submerging Coasts; John Wiley and Sons: Chichester, UK, 1993; p. 184.

2. Hsu, T.-W.; Lin, T.-Y.; Tseng, I.-F. Human Impact on Coastal Erosion in Taiwan. J. Coast. Res. 2007, 234, 961-973. [CrossRef]

3. Frihy, E.O. The necessity of environmental impact assessment (EIA) in implementing coastal projects: Lessons learned from the Egyptian Mediterranean Coast. Ocean Coast. Manag. 2001, 44, 489-516. [CrossRef]

4. Hynes, S.; Farrelly, N. Defining standard statistical coastal regions for Ireland. Mar. Policy 2012, 36, 393-404. [CrossRef]

5. Christian, R.R.; Baird, D.; Bowen, R.E.; Clark, D.M.; de Mora, S.; Di Giacomo, P.M.; Jiménez, J.; Kineman, J.; Mazzilli, S.; Servin, G.; et al. Coastal GTOS Strategic Design and Phase 1 Implementation Plan; Food and Agriculture Organization of the United Nations (FAO): Rome, Italy, 2005; Available online: http:/ / www.fao.org/3/a0266e/a0266e07.htm (accessed on 6 October 2021).

6. Yin, Z. The cases of coastal ecological engineering in Germany. In Collection of Cases of Ecological Engineering; Public Construction Commission: Taipei, Taiwan, 2004; pp. 355-388.

7. Construction and Planning Agency, Ministry of the Interior (CPAMI), Coastal Zone Management Act 2015. Available online: https: / / www.cpami.gov.tw/news/laws-regulations / 6-land-use-planning/18609-coastal-zone-management-act \%EF\%BC\%88 \%E6\%B5\%B7\%E5\%B2\%B8\%E7\%AE\%A1\%E7\%90\%86\%E6\%B3\%95\%EF\%BC\%89.html (accessed on 14 July 2021).

8. Lan, Y.J.; Hsu, T.W.; Lee, Y.T.; Shin, C.Y.; Chou, Y.C.; Huang, W.S. Relationship between the coastal buffer zone and ecological habitat. In Proceedings of the 29th Ocean Engineering Conference in Taiwan, Tainan, Taiwan, 29-30 November 2007; pp. 721-726.

9. SPB-NBDELG. A Coastal Areas Protection Policy for New Brunswick; Sustainable Planning Branch, Department of the Environment and Local Government: Fredericton, NB, Canada, 2002; p. 18.

10. Mustelin, J.; Asseid, B.; Haji, T.; Khamis, M.; Klein, R.; Mzee, A.; Sitari, T. Practical Measures to Tackle Climate Change: Coastal Forest Buffer Zones and Shoreline Change in Zanzibar, Tanzania; Department of Geography, University of Turku: Turku, Finland, 2009; p. 110.

11. Herath, S.; Hidayat, R. Enhancing coastal resilience in Asia against climate change: Challenges and measures. In Proceedings of the International Symposium on Coastal Zones and Climate Change: Assessing the Impacts and Developing Adaptation Strategies, Melbourne, Australia, 12-13 April 2010; pp. 407-417.

12. Wescott, G. Implementing climate change policies consistent with Integrated Coastal Zone Management: A case study of Victoria, Australia. In Proceedings of the International Symposium on Coastal Zones and Climate Change: Assessing the Impacts and Developing Adaptation Strategies, Melbourne, Australia, 12-13 April 2010; pp. 385-394.

13. Stevens, H.R.; Kiem, A.S. Developing Hazard Lines in Response to Coastal Flooding and Sea Level Change. Urban Policy Res. 2014, 32, 341-360. [CrossRef]

14. RI Coastal Resources Management Council (RICRMC). CRMC Coastal Buffer Zone Management Guidance; Coastal Resources Management Council: Wakefield, RI, USA, 2016; p. 9.

15. Davar, L.; Griggs, G.; Danehkar, A.; Salmanmahiny, A.; Azarnivand, H.; Naimi, B. A Spatial Integrated SLR Adaptive Management Plan Framework (SISAMP) toward Sustainable Coasts. Water 2021, 13, 2263. [CrossRef]

16. Westbrook, S.; Rayner, J.; Davis, G.; Clement, T.; Bjerg, P.L.; Fisher, S. Interaction between shallow groundwater, saline surface water and contaminant discharge at a seasonally and tidally forced estuarine boundary. J. Hydrol. 2005, 302, 255-269. [CrossRef]

17. Naiman, R.J.; Decamps, H.; Pollock, M. The Role of Riparian Corridors in Maintaining Regional Biodiversity. Ecol. Appl. 1993, 3, 209-212. [CrossRef]

18. Schultz, R.C.; Kuehl, A.; Colletti, J.P.; Wray, P.H.; Isenhart, T.M. Riparian Buffer Systems; Agriculture and Environment Extension Publication. 1997, p. 219. Available online: http:/ /lib.dr.iastate.edu/extension_ag_pubs/219 (accessed on 30 July 2021 ).

19. Lowrance, R. Riparian Forest Ecosystems as Filters for Nonpoint-Source Pollution. In Successes, Limitations, and Frontiers in Ecosystem Science; Springer: New York, NY, USA, 1998; pp. 113-141. [CrossRef]

20. Shultz, S.D.; Leitch, J.A. The feasibility of restoring previously drained wetlands to reduce flood damage. J. Soil Water Conserv. 2003, 58, 21-29.

21. Lovell, S.T.; Sullivan, W.C. Environmental benefits of conservation buffers in the United States: Evidence, promise, and open questions. Agric. Ecosyst. Environ. 2006, 112, 249-260. [CrossRef]

22. Macfarlane, D.M.; Bredin, I.P.; Adams, J.B.; Zungu, M.M.; Bate, G.C.; Dickens, C.W.S. Preliminary Guideline for the Determination of Buffer Zones for Rivers, Wetlands and Estuaries; Final Consolidated Report. WRC Report No. TT 610/14; Water Research Commission: Pretoria, South Africa, 2014; p. 208. 
23. Sawatzky, M.E.; Fahrig, L. Wetland buffers are no substitute for landscape-scale conservation. Ecosphere 2019,10 , e02661. [CrossRef]

24. Desbonnet, A.; Lee, V.; Pogue, P.; Reis, D.; Boyd, J.; Willis, J.; Imperial, M. Development of coastal vegetated buffer programs. Coast. Manag. 1995, 23, 91-109. [CrossRef]

25. Yagi, H.; Hinata, H.; Nadaoka, K. Velocity field measurements in a "Coastal Buffer Zone". In Proceedings of the 25th International Conference on Coastal Engineering, ASCE, Orlando, FL, USA, 2-6 September 1996; pp. 3431-3441.

26. Kuo, Y.Y.; Chang, C.C. The Cases of Coastal Ecological Engineering in Japan. In Collection of Cases of Ecological Engineering; Public Construction Commission: Taipei, Taiwan, 2004; pp. 339-354.

27. Park, J.; Yoo, C.-I.; Yoon, H.-S. Use of Groundwater-table To Establish a Buffer Zone In a Barrier Island, Nakdong River Estuary, South Korea. J. Coast. Res. 2016, 75, 113-117. [CrossRef]

28. NCKU Research and Development Foundation (NCKURDF). A Study on Mechanism of Topographical Changes after Coastal Development from Aogu to Tsengwen Coast (2/3); Water Resources Planning Institute, Water Resources Agency, Ministry of Economic Affairs: Taichung, Taiwan, 2004; p. 243.

29. Kuo, C.T. Coastal remediation and application of ecological engineering methods. In Collection of Cases of Ecological Engineering; Public Construction Commission: Taipei, Taiwan, 2004; pp. 315-338.

30. Mase, H. Random Wave Runup Height on Gentle Slope. J. Waterw. Port, Coastal, Ocean Eng. 1989, 115, 649-661. [CrossRef]

31. De Waal, J.P.; van der Meer, J.W. Wave runup and overtopping on coastal dikes. In Proceedings of the 23rd International Conference on Coastal Engineering, ASCE, Venice, Italy, 4-9 October 1992; pp. 1758-1771.

32. Long-Wave Runup Models. In Proceedings of the Second International Workshop on Long-Wave Runup Models, Washington, DC, USA. 12-17 September 1995; Yeh, H.; Liu, P.; Synolakis, C. (Eds.) World Scientific: Singapore, 1997; p. 420. [CrossRef]

33. Hsu, T.; Lan, Y.; Lin, Y. Extended wind wave model (WWM) incorporating the effect of submerged porous media with high permeability. Coast. Eng. 2018, 140, 87-99. [CrossRef]

34. Zalesny, V.B.; Gusev, A.V.; Lukyanova, A.N.; Fomin, V.V. Numerical modelling of sea currents and tidalwaves. Russ. J. Numer. Anal. Math. Model. 2016, 31, 115-125. [CrossRef]

35. Svendsen, I.A.; Haas, K.; Zhao, Q. Quasi-3D Nearshore Circulation Model SHORECIRC.; Internal Rep., CACR-02-01; Center for Applied Coastal Research, University of Delaware: Newark, DE, USA, 2002.

36. Pao, C.-H.; Chen, J.-L.; Su, S.-F.; Huang, Y.-C.; Huang, W.-H.; Kuo, C.-H. The Effect of Wave-Induced Current and Coastal Structure on Sediment Transport at the Zengwen River Mouth. J. Mar. Sci. Eng. 2021, 9, 333. [CrossRef]

37. Dayan, H.; Le Cozannet, G.; Speich, S.; Thiéblemont, R. High-End Scenarios of Sea-Level Rise for Coastal Risk-Averse Stakeholders. Front. Mar. Sci. 2021, 8, 569992. [CrossRef]

38. Dube, S.K.; Murty, T.S.; Feyen, J.C.; Cabrera, R.; Harper, B.A.; Bales, J.D.; Amer, S.; Chan, J.C.L.; Kepert, J.D. Storm Surge Modeling and Applications in Coastal Areas. In Global Perspectives on Tropical Cyclones: From Science to Mitigation; World Scientific: Singapore, 2010; pp. 363-406. [CrossRef]

39. Kim, Y.-J.; Kim, T.-W.; Yoon, J.-S. Study on Storm Surge Using Parametric Model with Geographical Characteristics. Water 2020, 12, 2251. [CrossRef]

40. Muis, S.; Apecechea, M.I.; Dullaart, J.; Rego, J.D.L.; Madsen, K.S.; Su, J.; Yan, K.; Verlaan, M. A High-Resolution Global Dataset of Extreme Sea Levels, Tides, and Storm Surges, Including Future Projections. Front. Mar. Sci. 2020, 7, 1-15. [CrossRef]

41. Gallien, T.W.; Kalligeris, N.; Delisle, M.P.C.; Tang, B.X.; Lucey, J.T.D.; Winters, M.A. Coastal flood modeling challenges in defended urban backshores. Geosciences 2018, 8, 450. [CrossRef]

42. Xie, D.; Zou, Q.-P.; Mignone, A.; MacRae, J.D. Coastal flooding from wave overtopping and sea level rise adaptation in the northeastern USA. Coast. Eng. 2019, 150, 39-58. [CrossRef]

43. Hanson, H. Genesis: A generalized shoreline change numerical model. J. Coast. Res. 1989, 5, 1-27.

44. Larson, M.; Kraus, N.C. SPEECH-Numerical Model for Simulating Storm-Induced Beach Change, Report 1, Empirical Foundation and Model Development, Tech. Rep. CERC-89-9; Coastal Engineering Research Center, U.S. Army Corps of Engineers: Washington, DC, USA, 1989; p. 266.

45. Prasad, D.H.; Kumar, N.D. Coastal Erosion Studies-A Review. Int. J. Geosci. 2014, 05, 341-345. [CrossRef]

46. Hsu, J.R.C.; Evans, C. Parabolic Bay Shapes and Applicat IONS. Proc. Inst. Civ. Eng. 1989, 87, 557-570. [CrossRef]

47. Weesakul, S.; Rasmeemasmuang, T.; Tasaduak, S.; Thaicharoen, C. Numerical modeling of crenulate bay shapes. Coast. Eng. 2010, 57, 184-193. [CrossRef]

48. Li, B.; Zhuang, Z.; Cao, L.; Du, F. Application of the Static Headland-Bay Beach Concept to a Sandy Beach: A New Elliptical Model. J. Ocean Univ. China 2020, 19, 81-89. [CrossRef]

49. Giudice, A.L.; Preziosi, L. A fully Eulerian multiphase model of windblown sand coupled with morphodynamic evolution: Erosion, transport, deposition, and avalanching. Appl. Math. Model. 2019, 79, 68-84. [CrossRef]

50. James, I. Modelling pollution dispersion, the ecosystem and water quality in coastal waters: A review. Environ. Model. Softw. 2002, 17, 363-385. [CrossRef]

51. Larson, M.; Bellanca, R.; Jonsson, L.; Chen, C.; Shi, P. A Model of the 3D Circulation, Salinity Distribution, and Transport Pattern in the Pearl River Estuary, China. J. Coast. Res. 2005, 215, 896-908. [CrossRef]

52. Pu, L.; Xin, P.; Nguyen, T.T.M.; Yu, X.; Li, L.; Barry, D.A. Thermal Effects on Flow and Salinity Distributions in Coastal Confined Aquifers. Water Resour. Res. 2020, 56. [CrossRef] 
53. Xu, Y.; Cai, Y.; Peng, J.; Qu, J.; Yang, Z. Spatial distribution of flow currents and habitats in artificial buffer zones for ecosystembased coastal engineering. Glob. Ecol. Conserv. 2019, 20, e00764. [CrossRef]

54. Sulaiman, R.B.R.; Mohidin, F.S.M. Establishment of Shoreline Buffer Zone through Rehabilitation of Degraded Coastal Mangroves. International Conference on Civil, Offshore \& Environmental Engineering 2018 (ICCOEE 2018). MATEC Web Conf. 2018, 203, 01019. [CrossRef]

55. Lan, Y.J.; Hsu, T.W.; Chou, Y.C.; Lee, Y.T. A study on coastal buffer zone and application to Howmeiliao Coast. In Proceedings of the 30th Ocean Engineering Conference in Taiwan, Hsinchu, Taiwan, 13-14 November 2008; pp. 667-672.

56. Lan, Y.J.; Hsu, T.W.; Wu, B.C.; Lee, Y.T. A study on coastal buffer zone at Taiwanese coasts. In Proceedings of the 32nd Ocean Engineering Conference in Taiwan, Keelung, Taiwan, 25-26 November 2010; pp. 581-586.

57. Li, Y.T. Demarcating Coastal Buffer Zone by Coastal Nearshore Hydrodynamic and Sediment Transport. Ph.D. Thesis, National Cheng Kung University, Tainan, Taiwan, 21 July 2011.

58. Shie, W.Z. A Study on the Analysis of Relationship between Coastal Buffer Zone and Natural Protected Area-Typical Example at Howmeiliao Coast. Master's Thesis, National Cheng Kung University, Tainan, Taiwan, 21 May 2009.

59. Chiau, W.Y. Coastal Management: Theory and Practice; National Institute for Compilation and Translation (edit.); Wu-Nan Book Co., Ltd.: Taipei, Taiwan, 2003; p. 494.

60. Lan, Y.J.; Hsu, T.W.; Shie, W.Z.; Lee, Y.T. A study on the analysis of relationship between coastal buffer zone and natural protected area-typical example at Howmeiliao Coast. In Proceedings of the 31st Ocean Engineering Conference in Taiwan, Taichung, Taiwan, 26-27 November 2009; pp. 627-632.

61. Costanza, R.; Andrade, F.; Antunes, P.; Belt, M.V.D.; Boersma, D.; Boesch, D.F.; Catarino, F.; Hanna, S.; Limburg, K.; Low, B.; et al. Principles for Sustainable Governance of the Oceans. Science 1998, 281, 198-199. [CrossRef] [PubMed]

62. National Land Planning and Real Estate Information Center (NLPREIC). Territorial Planning Pre-Work Handling Plan-Sub-Project 3: Definition of Territorial Planning Sea Area and Research on Planning Issues; Research Report Commissioned by Construction and Planning Agency, Ministry of the Interior; National Land Planning and Real Estate Information Center (NLPREIC): Taipei, Taiwan, 2006; p. 187.

63. Laws and Regulations Database of the Republic of China (LRDROC). Environmental Impact Assessment Guidelines for Development Behaviors, 2021. Available online: https:/ /law.moj.gov.tw /LawClass /LawAll.aspx?pcode=O0090003 (accessed on 14 July 2021).

64. Tseng, H.Y. A Study on the Legalization of Planning and Development in Taiwan Coastal Areas. Master's Thesis, National Taiwan University, Taipei, Taiwan, 2001.

65. Chiau, W.Y. Artificial wetland and its application in landscape ecology. In Collection of Cases of Ecological Engineering; Public Construction Commission: Taipei, Taiwan, 2004; pp. 389-418. 